\title{
Revista Brasileira de Fruticultura \\ Physiology and quality of Eugenia dysenterica DC seedlings grown in vermiculite and rice husk-based substrates
}

\author{
Clenilso Sehnen Mota ${ }^{1}$, Eduard Lucas Souza Araújo ${ }^{2}$, Fabiano Guimarães Silva ${ }^{3}$, \\ Paulo Dornelles ${ }^{4}$, Mariângela Brito Freiberger ${ }^{5}$, Giselle Camargo Mendes ${ }^{6}$
}

\begin{abstract}
Eugenia dysenterica DC is a fruiting species endemic to the Brazilian Cerrado, belonging to the Myrtaceae family and popularly known as Cagaiteira. It has medicinal and antifungal properties, and has an important function in the ecosystem. Nevertheless, there are few studies about the maintenance of this species. The aim of this study was to evaluate the growth, nutrition, quality and physiology of $E$. dysenterica seedlings grown in fine vermiculite and rice husk-based substrates in the following combinations: $1: 0,3: 1,1: 1$, and $1: 3$, in addition to Trimix ${ }^{\circledR}$ commercial substrate and vermiculite only. The physical attributes of substrates (dry and moist densities, available water, remaining water, aeration space and total porosity), seedling emergence percentage, emergence speed index, gas exchange, chlorophyll $a$ fluorescence, relative seedling water content, relative substrate moisture content, plant biometric growth characteristics, accumulated dry weight and nutritional status were evaluated through leaf macronutrient content 128 days after emergence. The increase in the proportion of rice husk mixed with vermiculite resulted in reduction of the dry and moist densities of substrates, available water, remaining water, total porosity and moisture content, and increased the aeration space in substrates. The fine vermiculite substrate promoted the highest Dickson's quality index and the greatest stem diameter of plants. Seedlings grown on vermiculite substrate presented higher $\mathrm{N}$ and $\mathrm{K}$ content in leaves, and those grown in Trimix ${ }^{\circledR}$ substrate showed higher leaf Mg content. Substrates did not alter the physiological attributes of seedlings.
\end{abstract}

Index terms: cagaita, gas exchange, fluorescence, quality index.

\section{Fisiologia e qualidade de mudas de Eugenia dysenterica DC, produzidas em substratos em base de vermiculita e casca de arroz carbonizada}

Corresponding author:

E-mail: csm.sehnen@gmail.com Received: July 06, 2016. Accepted: February 14, 2017.

Copyright: All the contents of this journal, except where otherwise noted, is licensed under a Creative Commons Attribution License.

\section{(cc) $\mathrm{EY}$}

\begin{abstract}
Resumo - A Eugenia dysenterica DC é uma espécie de frutífera endêmica do Cerrado, pertence à família Myrtaceae e é popularmente conhecido como cagaiteira. Apresenta propriedades medicinais e antifúngicas, e tem função importante no ecossistema. No entanto, existem poucos estudos sobre a manutenção da espécie. O objetivo deste estudo foi avaliar o crescimento, a nutrição, a qualidade e a fisiologia de mudas $E$. dysenterica cultivadas em substratos à base de vermiculita fina e casca de arroz carbonizada, nas seguintes combinações: 1:0; 3:1; 1:1 e 1:3, além do substrato comercial Trimix ${ }^{\circledR}$ e apenas vermiculita. Avaliaram-se os atributos físicos dos substratos (densidades seca e úmida, água disponível, água remanescente, espaço de aeração e porosidade total), a porcentagem de emergência de plântulas, o índice de velocidade de emergência, as trocas gasosas, a fluorescência da clorofila a, o teor relativo de água das mudas, o teor de umidade relativa do substrato, as características biométricas de crescimento de plantas, o acúmulo de massa seca e o estado nutricional através do conteúdo de macronutrientes nas folhas, após 128 dias da emergência. O incremento na proporção de casca de arroz misturada com vermiculita reduziu as densidades seca e úmida, a água disponível, a água remanescente, a porosidade total e o teor de umidade, e aumentou o espaço de aeração nos substratos. O substrato vermiculita pura promoveu o maior índice de qualidade de Dickson, bem como o maior diâmetro de colo, apesar de ser o substrato no qual as plantas apresentaram menor índice de velocidade de emergência. As plantas crescidas no substrato vermiculita pura apresentaram maior teor de $\mathrm{N}$ e $\mathrm{K}$ nas folhas, e as crescidas no subtrato Trimix ${ }^{\circledR}$ apresentaram maior teor foliar de Mg. Os substratos não alteraram os atributos fisiológicos das mudas.
\end{abstract}

Termos para indexação: cagaita, trocas gasosas, fluorescência, índice de qualidade.

\footnotetext{
${ }^{1}$ Agronomist, PhD, Professor, Instituto Federal Catarinense. Study supported by CAPES - Higher Education Personnel Improvement Coordination Email: csm.sehnen@gmail.com

${ }^{2}$ Agronomist. Email: eduard.agro@hotmail.com

${ }^{3}$ Degree in Agricultural Science, PhD, Professor, Instituto Federal Goiano. Email: fabianoifgoiano@gmail.com

${ }^{4}$ Biologyst, PhD, Instituto Federal Goiano. E-mail: dornellesifgoiano@gmail.com

${ }^{5}$ Agronomist, PhD, Postdoctoral Researcher, Instituto Federal Goiano. Email: maia_bf@yahoo.com.br

${ }^{6}$ Biologyst, PhD, Professor, Instituto Federal Catarinense. Email: giselle.mendes@ifc.edu.br
} 


\section{Introducition}

The Brazilian Cerrado (tropical savanna) is considered the second largest Brazilian biome and shelters a great diversity of plant species (PAIVA SOBRINHO et al., 2010). Eugenia dysenterica DC is a fruiting species endemic to the Brazilian Cerrado (SOUZA et al., 2013), belonging to the Myrtaceae family and popularly known as Cagaiteira. E. dysenterica fruits are considered an important source of vitamins $\mathrm{C}$ and A (CARDOSO et al., 2011) and the extract of its leaves has anti-diarrheal activity, so that the plant is promising as a new medication (LIMA et al., 2010). Cagaita leaf extracts are also known for their antifungal properties (COSTA et al., 2000; SOUZA et al., 2012) and inhibit the $\alpha$-amylase and $\alpha$-glycosidase activity, which can be important in controlling diabetes. Despite the socioeconomic and ecologic importance of E. dysenterica, (BAILÃO et al., 2015), there are few studies about the maintenance of the species. The cultivation of native species through seedling propagation can be an effective way to avoid biodiversity loss in the Cerrado biome.

The production of healthy, robust, well-nourished and high-quality seedlings is required for the propagation of woody plant species after transplantation in the field, resulting in successful establishment of fruit orchards and even reforested areas (GOMES et al., 2003). The substrate where root develops is one of the factors that influence seedling quality through the ability to supply structural support for root development and water, oxygen, and nutrients (FERRAZ et al., 2005). A good substrate, to favor germination and emergence, must exhibit a degree of porosity allowing seed hydration and aeration. Thus, characteristics such as substrate density, aeration space, available water, remaining water and total porosity are relevant (NOGUEIRA et al., 2003). Moreover, the substrate must exhibit slow decomposition, high cation-exchange capacity, be free from pathogens and seeds of undesired plants; and must be available on the market at affordable prices (DANTAS et al., 2009). These characteristics are obtained by mixing two or more components, which together will form substrate suitable for seedling formation (ARAÚJO NETO et al., 2009).

Studies on substrates are necessary to discover new possible formulations, such as the use of agroindustrial, forestry, and urban wastes (MARTINS et al., 2011). The use of such waste for seedling production may be a feasible alternative because large volumes of these wastes are generated and create environmental problems when not adequately disposed. Single materials and combinations of different types of materials are used for seedling production, which can be produced in greenhouse or acquired from specialized companies. The use of expanded vermiculite and rice husk is common to produce seedlings of forest species (SILVA et al., 2012; DELARMELINA et al., 2014). However, the use of these components to produce seedlings of Cerrado native species is still incipient.

Biometric parameters that consider the balance between root and shoot weights; measurements that provide robustness quotient; indexes such as the fairly complex index of quality created by Dickson et al. (1960), which consider seedling total dry weight, root to shoot ratio, and stem length/stem diameter Silveira et al. (2013); and gas exchange and chlorophyll a fluorescence measures are potential indicators of seedling quality and stress (BARALDI et al., 2008; NEVES et al., 2009). Thus, to contribute to information on seedling production and quality of native Cerrado species, the main purpose of this study was to evaluate the growth, quality, mineral content in leaves and physiology of Eugenia dysenterica DC. seedlings produced in cartridges using vermiculite and rice husk-based substrates.

\section{Materials and Methods}

E. dysenterica DC fruits were harvested from healthy adult plants, in full production, at Gameleira Farm located in Montes Claros de Goiás, GO, Brazil. Fruits were transported to the Laboratory of Plant Tissue Culturing (LCTV) of the Goiano Federal Institute, Campus of Rio Verde, being pulped and removing seed coats to facilitate germination. The study was conducted in greenhouse at LCTV. Temperature and relative humidity inside the greenhouse were recorded using a data logger. The mean temperature and relative humidity were $25.5^{\circ} \mathrm{C}$ and $76 \%$, respectively.

Substrates were formulated based on fine vermiculite $(\mathrm{FV})$, partially carbonized rice husk $(\mathrm{RH})$, and Trimix ${ }^{\circledR}$ (containing FV, carbonized RH and coconut fiber, according to manufacturer's information), by testing $\operatorname{Trimix}^{\circledR}, \mathrm{FV}$ and $\mathrm{FV}+\mathrm{RH}$ at $3: 1,1: 1$, and $1: 3$ ratios $(\mathrm{v} / \mathrm{v})$, whose chemical characteristics are shown in Table 1. Cartridges of $288 \mathrm{~cm}^{3}$ were filled with substrates, in which one seed was added for germination. Spray irrigation was $12 \mathrm{~mm}$ day $^{-1}$, divided into two daily irrigations. Seedling emergence percentage (SEP) was tested at two-day intervals between emergence of the first seedling and the end of emergence and the emergence speed index (ESI) was calculated according to Maguire (1962).

For the determination of the dry (DD) and moist (MD) density, the method described by Rober and Schaller (1985) was used. The capacity of the beaker used was 250 $\mathrm{cm}^{3}$ and to obtain the dry matter, samples were dried at $65^{\circ} \mathrm{C}$ until constant mass. For the other physical analyses, substrate samples were placed in rings of 40 and $50 \mathrm{~mm}$ in diameter and height, respectively. After saturation with distilled water for a period of $24 \mathrm{~h}$, rings containing substrates were packed in funnels containing porous plate next to the suction unit. Then, rings were subjected to tensions of 1 and $10 \mathrm{kPa}$. At saturation, i.e., at tension of $0 \mathrm{kPa}$, and at 1 and $10 \mathrm{kPa}$, the moist and dry mass of the set (ring + substrate) was determined in a semi analytical scale. Tensions of 0,1 and $10 \mathrm{kPa}$ were used to calculate 
the total porosity (TP), available water (AW), remaining water (RW) and aeration space (AS) according to De Boodt and Verdonck (1972).

Seedling gas exchange, fluorescence, growth, quality and water content, as well as substrate moisture content, were evaluated at 128 days after seeding. Gas exchange was evaluated in the morning between 7:30 and 11:30 am using LCi portable photosynthesis meter (ADC BioScientific, Great Amwell, United Kingdom), that generated the following variables: net $\mathrm{CO}_{2}$ assimilation $(A)$, transpiration $(E)$, water use efficiency $(A / E)$ obtained from the $A$ / $E$ ratio, and stomatal conductance $\left(g_{s}\right)$. The chlorophyll $a$ fluorescence variables were obtained using Mini-PAM modulated fluorometer (Walz, Effeltrich, Germany). The maximum quantum yield of photosystem II (PSII) $\left(\mathrm{F}_{\mathrm{v}} / \mathrm{F}_{\mathrm{m}}\right)$ was calculated using the darkness parameters with the following equation: $\mathrm{F}_{\mathrm{v}} / \mathrm{F}_{\mathrm{m}}=\left(\mathrm{F}_{\mathrm{m}}-\mathrm{F}_{0}\right)$ $/ \mathrm{F}_{\mathrm{m}}$, where $\mathrm{F}_{0}$ and $\mathrm{F}_{\mathrm{m}}$ are the minimum and maximum fluorescence, respectively, of the dark-adapted plant tissue obtained before dawn. $\mathrm{F}_{0}$ was obtained by illuminating the plant tissue with a low-intensity modulated red light $\left(0.03 \mu \mathrm{mol} \mathrm{m}^{-2} \mathrm{~s}^{-1}\right)$, and $\mathrm{F}_{\mathrm{m}}$ was obtained with a saturating light pulse $\left(6,000 \mu \mathrm{mol} \mathrm{m} \mathrm{m}^{-2} \mathrm{~s}^{-1}\right)$ lasting 0.8 seconds. The effective quantum yield of PSII ( $\phi$ PSII) was calculated using the following equation: $\phi \mathrm{PSII}=\left(\mathrm{F}_{\mathrm{m}}{ }^{\prime}-\mathrm{F}\right) / \mathrm{F}_{\mathrm{m}}$, where $\mathrm{F}_{\mathrm{m}}$ ' and $\mathrm{F}$ are the maximum fluorescence and fluorescence, respectively, when the plant tissue is under actinic light at intensity of $1,000 \mu \mathrm{mol} \mathrm{m}^{-2} \mathrm{~s}^{-1}$ for 50 seconds. The quantum yield of regulated non-photochemical energy dissipation of PSII ( $\phi N P Q)$ and the quantum yield of unregulated non-photochemical energy dissipation of PSII $(\phi N O)$ were obtained according to Hendrickson et al. (2004). The apparent electron transport rate of PSII (ETR) was obtained from Bilger et al. (1995).

Relative water content (RWC) and substrate moisture content were measured before dawn at 4:30 a.m. To determine RWC, one leaf per plant was collected using a scalpel and immediately weighed on an analytical scale to obtain the fresh weight (FW). After obtaining $\mathrm{FW}$, leaves were placed in a humid chamber, and petioles were immersed in distilled water, remaining under these conditions for 24 hours at $25^{\circ} \mathrm{C}$, with compensation irradiance to allow leaves to reach maximum turgor. After reaching maximum turgor, leaves were weighed to obtain the turgid weight (TW) and were then dried in a forced-air oven at $65^{\circ} \mathrm{C}$ to constant weight, yielding the dry weight (DW). RWC was calculated using the following equation: $\mathrm{RWC}=(\mathrm{FW}-\mathrm{DW}) /(\mathrm{TW}-\mathrm{DW})$. To determine the relative moisture of substrates, samples were collected from the same cartridges containing the plants used to determine RWC. Immediately after collection, substrates were weighed on a semi-analytical scale to obtain the wet weight (WW) and then dried in a forced-air oven at $105^{\circ} \mathrm{C}$ to constant weight, yielding the substrate dry weight (DWs). To obtain the relative moisture content of the substrate $(\mathrm{RMC})$ on a dry basis, the $\mathrm{RMC}=(\mathrm{WW}$ DWs) / DWs equation was used.
After 128 days of emergence, stalk diameter (SD) and leaf number of seedlings (NL) were measured, which were separated into stem, leaves and root. Stem length (SL) and leaf area (LA) were also obtained. Stems, leaves, and roots were dried in a forced-air oven at $65^{\circ} \mathrm{C}$ to constant weight, to obtain weights separately. The SL/ $\mathrm{SD}$ ratio (SL/SD), the root dry weight / shoot dry weight ratio $(\mathrm{R} / \mathrm{S})$, and the Dickson's quality index (DQI) were used as seedling quality parameters according to Dickson et al. (1960). Leaves from plants of each replicate were combined and ground in a Willey mill to determine the content of macronutrients according to Malavolta et al. (1997).

The experiment followed a randomized block design with five replicates and 20 cartridges per replicate for PSE and ESI, two for RWC and RMC, one for gas exchange and fluorescence, and five for the other evaluations. Data were submitted to analysis of variance and Tukey test. Significance level of 5\% was used to discriminate the minimal significant differences among means. Statistical analysis was performed using the SAEG computational software version 9.1. 
Table 1 - Chemical analysis of the macro and micronutrients of substrates. Rio Verde, 2016.

\begin{tabular}{|c|c|c|c|c|c|c|}
\hline Substrate & $\mathrm{pH}^{\mathrm{k}}$ & $\mathrm{V}$ & $\mathrm{Ca}$ & $\mathrm{Mg}$ & $\mathrm{P}$ & $\mathrm{K}$ \\
\hline & & $\%$ & & \multicolumn{3}{|c|}{$\mathrm{mg} \mathrm{dm}{ }^{-3}$} \\
\hline Trimix ${ }^{\circledR}$ & 6.42 & 79.0 & 0.33 & 2.92 & 2.8 & 447 \\
\hline $\mathrm{FV}^{\mathrm{x}}$ & 6.76 & 88.9 & 0.20 & 7.76 & 9.9 & 11 \\
\hline $\mathrm{FV}+\mathrm{RH}^{\mathrm{w}}(3: 1)$ & 6.41 & 86.6 & 0.34 & 7.69 & 5.8 & 125 \\
\hline FV+RH (1:1) & 6.79 & 83.6 & 0.21 & 6.10 & 8.1 & 119 \\
\hline \multirow[t]{3}{*}{ FV+RH (1:3) } & 6.79 & 71.0 & 0.26 & 3.49 & 15.4 & 227 \\
\hline & $\mathrm{Na}$ & $\mathrm{Zn}$ & $\mathrm{Fe}$ & $\mathrm{Mn}$ & $\mathrm{Cu}$ & $\mathrm{B}$ \\
\hline & \multicolumn{5}{|c|}{ 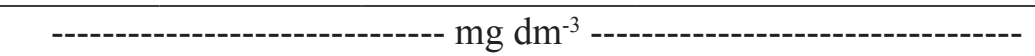 } & \\
\hline Trimix ${ }^{\circledR}$ & 114.8 & 1.49 & 145.1 & 14.7 & 0.65 & 0.29 \\
\hline $\mathrm{FV}^{\mathrm{x}}$ & 2.1 & 0.42 & 65.7 & 7.2 & 0.43 & 0.12 \\
\hline $\mathrm{FV}+\mathrm{RH}^{\mathrm{w}}(3: 1)$ & 10.2 & 0.92 & 107.5 & 15.5 & 0.56 & 0.14 \\
\hline $\mathrm{FV}+\mathrm{RH}(1: 1)$ & 6.1 & 0.97 & 88.0 & 12.8 & 0.45 & 0.22 \\
\hline $\mathrm{FV}+\mathrm{RH}(1: 3)$ & 16.2 & 8.47 & 80.9 & 17.4 & 0.33 & 0.45 \\
\hline
\end{tabular}

${ }^{\mathrm{x}}$ Fine vermiculite; ${ }^{\mathrm{w}}$ Rice husk; ${ }^{\mathrm{k}} \mathrm{pH}$ in $\mathrm{H}_{2} \mathrm{O}$

\section{Results and Discussion}

The highest dry density (DD) values were presented by $\mathrm{FV}+\mathrm{RH}(3: 1)$ and $\mathrm{FV}+\mathrm{RH}(1: 1)$ substrates, and corresponded to 168.3 and $166.3 \mathrm{~kg} \mathrm{~m}^{-3}$ respectively, whereas for the moist density (MD), the highest value was verified for the FV substrate. DD value suitable for substrates is $500 \mathrm{~kg} \mathrm{~m}^{-3}$, while the MD value is $1,000 \mathrm{~kg}$ $\mathrm{m}^{-3}$ (KÄMPF, 2000). According to these criteria, DD and MD values of substrates used in the present study are below those considered suitable (Table 2). Low-density substrates are more suitable for use in trays (FERMINO et al., 2010; KÄMPF, 2000).
Trimix $^{\circledR}$ substrate presented the highest amount of available water (AW) between 1 and $10 \mathrm{kPa}$, followed by FV+RH (3:1) (Table 2). However, no substrate studied presents the recommended DW range $\left(0.20\right.$ to $\left.0.30 \mathrm{~m}^{3} \mathrm{~m}^{-3}\right)$ according to De Boodt and Ballester-Olmos (1974). These results indicate that the substrates may not have provided the amount of water required by plants. This occurred possibly because increasing the addition of $\mathrm{RH}$ to $\mathrm{FV}$ decreased the proportion of micropores in the substrate, reducing its water retention capacity, and hence the amount of available water. Guerrini and Trigueiro (2004) also found that increasing the proportion of rice husk in the substrate promoted a reduction in the proportion of micropores in the substrate, reducing its water retention capacity.

Table 2- Dry density (DD), moist density (MD), available water (AW), remaining water (RW), aeration space (AS) and total porosity (TP) as a function of substrates. Rio Verde, 2016.

\begin{tabular}{|c|c|c|c|c|c|c|}
\hline Substrate & $\mathrm{DD}$ & $\mathrm{MD}$ & AW & RW & AS & $\mathrm{TP}$ \\
\hline & \multicolumn{2}{|c|}{$----\mathrm{kg} \mathrm{m}^{-3}$----- } & \multicolumn{4}{|c|}{---------------------- $\mathrm{m}^{3}$ m³ -------------------- } \\
\hline Trimix $^{\circledR}$ & $159.4 \mathrm{~b}$ & $546.5 \mathrm{~b}$ & $0.156 \mathrm{a}$ & $0.274 \mathrm{c}$ & $0.203 \mathrm{c}$ & $0.633 \mathrm{~d}$ \\
\hline $\mathrm{FV}^{\mathrm{x}}$ & $159.1 \mathrm{~b}$ & $622.6 \mathrm{a}$ & $0.075 \mathrm{c}$ & $0.372 \mathrm{a}$ & $0.318 \mathrm{~b}$ & $0.765 \mathrm{a}$ \\
\hline $\mathrm{FV}+\mathrm{RH}^{\mathrm{w}}(3: 1)$ & $168.3 \mathrm{a}$ & $558.6 \mathrm{~b}$ & $0.118 b$ & $0.344 \mathrm{~b}$ & $0.254 \mathrm{c}$ & $0.717 \mathrm{~b}$ \\
\hline $\mathrm{FV}+\mathrm{RH}(1: 1)$ & $166.3 \mathrm{a}$ & $561.9 \mathrm{~b}$ & $0.063 \mathrm{c}$ & $0.257 \mathrm{~d}$ & $0.352 \mathrm{a}$ & $0.672 \mathrm{c}$ \\
\hline FV+RH (1:3) & $149.6 \mathrm{c}$ & $470.6 \mathrm{~d}$ & $0.017 \mathrm{~d}$ & $0.115 \mathrm{e}$ & $0.345 \mathrm{a}$ & $0.476 \mathrm{e}$ \\
\hline $\mathrm{VC}^{\mathrm{v}}$ & 4.73 & 9.35 & 0.09 & 33.68 & 20.49 & 15.75 \\
\hline
\end{tabular}

*Means followed by the same letter in the column do not differ according to Tukey's test ( $\mathrm{p}<0.05)$; ${ }^{\mathrm{x}}$ Fine vermiculite; ${ }^{\text {w} R i c e ~ h u s k ; ~}{ }^{\mathrm{v}}$ Variation coefficient.

Trimix $^{\circledR}$ and $\mathrm{FV}+\mathrm{RH}(1: 1)$ were the only substrates presenting remaining water (RW) value $\left(0.25\right.$ to $\left.0.30 \mathrm{~m}^{3} \mathrm{~m}^{-3}\right)$ (Table 2) within range recommended by Verdonck and Gabriels (1988), which corresponded to 0.27 and 0.25 $\mathrm{m}^{3} \mathrm{~m}^{-3}$ respectively. FV and $\mathrm{FV}+\mathrm{RH}(3: 1)$ substrates, which presented values above recommendations, have the capacity to store water, but this is not available at tension lower than $10 \mathrm{kPa}$, which is that the plant can uptake. On the other hand, FV+RH (1:3) substrate had the lowest RW value and the lowest DW value. This is because $\mathrm{RH}$ is inert to hydration, and requires higher irrigation frequency (GUERRINI and TRIGUEIRO, 2004). When RW has values higher than recommendation, there may be excessive moisture problems to plant roots. On the other hand, low RW values can cause water deficiency in cultivated plants, thus requiring greater number of 
irrigations within shorter intervals (FERMINO 2003).

The aeration space (AS), which corresponds to the gas phase of the substrate under tension of less than 1 $\mathrm{kPa}$, presented adequate values, i.e., values above $0.30 \mathrm{~m}^{3}$ $\mathrm{m}^{-3}$ (PENNINGSFELD, 1983) for all substrates, except for Trimix ${ }^{\circledR}$ and FV+RH (3:1) (Table 2). FV, FV+RH (1:1) and FV+RH (1:3) substrates showed, however, the lowest AW values, which shows that they have good aeration but low hydration, requiring higher irrigation frequency to maintain air /water balance.

Total porosity (TP) was higher for FV $\left(0.765 \mathrm{~m}^{3}\right.$ $\left.\mathrm{m}^{-3}\right)$ substrate, followed by FV+RH (3:1), FV+RH (1:1), Trimix $^{\circledR}$ and FV+RH (1:3) (Table 2). All values are below porosity values recommended by De Boodt and Verdonck (1972), which is $85 \%$. Total porosity expresses the volume of substrate not occupied by particles and is defined as the difference between total volume and the volume of solids of a sample. Due to the fact that particles do not have regular sizes and are not spherical, as particle size increases, porosity also tends to increase. However, the mixing of particles of different sizes can decrease porosity due to the cementing effect that occurs when smaller particles fit into the free spaces formed among larger particles (DRZAL et al., 1999).

The seedling emergence percentage (SEP) of $E$. dysenterica remained unaffected by substrates, exhibiting mean emergence value of $99 \%$ (Table 3 ), which is unusual in woody plants. Emergence value of $80.6 \%$ in $E$. dysenterica seedlings grown in different substrates was reported by Souza et al. (2001). The emergence speed index (ESI) was lower in substrate containing only vermiculite $(0.30)$ compared to Trimix $^{\circledR}(0.34)$ (Table 3 ). According to Guerrini and Trigueiro (2004), adding carbonized rice husk to other materials is important to improve the physical structure of the substrate, as it is a light material inert to hydration and able to increase substrate porosity proportionally to its percentage in the mixture. ESIs found in the present study were higher than those found by Nietsche et al. (2004) of 0.08 and 0.1 for small and large cagaita seeds grown in different substrates, respectively. However, these authors did not report the removal of coats from seeds, a procedure that is believed to reduce the time to germination and emergence. In the present study, seed coat was removed by scarification to overcome the native seed dormancy.

Substrate containing only vermiculite was able to accumulate higher amount of water and exhibit the highest moisture content on a dry basis before dawn compared to the two other substrates with higher rice husk percentage, i.e., $\mathrm{FV}+\mathrm{RH}$ at 1:1 and 1:3 ratios (Table 4). In this case, the occurrence of lower water retention values is associated with higher amount of macropores inherent to carbonized rice husk. However, leaf relative water content remained unaffected by substrates, indicating that all substrates have the ability to adequately provide water to plants. The similarity in leaf relative water content of plants grown in the different substrates tested suggests that they were under the same water conditions and that the differences in substrates' moisture levels did not affect the water availability to plants.

Table 3 - Seedling emergence percentage (SEP) and emergence speed index (ESI) of Eugenia dysenterica DC seedlings in function of substrates. Rio Verde, 2016.

\begin{tabular}{lcc}
\hline Substrate & SEP & ESI \\
\hline Trimix $^{\circledR}$ & $\%$ & - \\
$\mathrm{FV}^{\mathrm{x}}$ & $100^{\mathrm{ns}}$ & $0.34 \mathrm{a}$ \\
$\mathrm{FV}+\mathrm{RH}^{\mathrm{w}}(3: 1)$ & 96 & $0.30 \mathrm{~b}$ \\
$\mathrm{FV}+\mathrm{RH}(1: 1)$ & 98 & $0.32 \mathrm{ab}$ \\
$\mathrm{FV}+\mathrm{RH}(1: 3)$ & 100 & $0.32 \mathrm{ab}$ \\
\hline $\mathrm{VC}^{\mathrm{v}}$ & 100 & $0.33 \mathrm{ab}$ \\
\hline
\end{tabular}

*Means followed by the same letter in the column do not differ according to Tukey's test $(\mathrm{p}<0.05)$; ${ }^{\mathrm{x}}$ Fine vermiculite; ${ }^{\mathrm{w}}$ Rice husk; ${ }^{\mathrm{v}}$ Variation coefficient. ns - not significant (Tukey $\mathrm{p}<0,05$ ).

Table 4- Relative moisture content (RMC) of the substrates on a dry basis and leaf relative water content (RWC) in Eugenia dysenterica DC seedlings as a function of substrates. Rio Verde, 2016.

\begin{tabular}{|c|c|c|}
\hline Substrate & $\mathrm{RMC}$ & RWC \\
\hline & \multicolumn{2}{|c|}{ 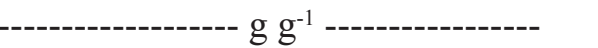 } \\
\hline $\operatorname{Trimix}^{\circledR}$ & $2.69 \mathrm{ab}$ & $0.97^{\mathrm{ns}}$ \\
\hline $\mathrm{FV}^{\mathrm{x}}$ & $3.49 \mathrm{a}$ & 0.97 \\
\hline $\mathrm{FV}+\mathrm{RH}^{\mathrm{w}}(3: 1)$ & $2.99 \mathrm{ab}$ & 0.96 \\
\hline FV+RH (1:1) & $2.17 \mathrm{bc}$ & 0.97 \\
\hline $\mathrm{FV}+\mathrm{RH}(1: 3)$ & $1.49 \mathrm{c}$ & 0.96 \\
\hline $\mathrm{VC}^{\mathrm{v}}$ & 31.67 & 2.08 \\
\hline
\end{tabular}

*Means followed by the same letter in the column do not differ according to Tukey's test $(\mathrm{p}<0.05)$; ${ }^{\mathrm{x}}$ Fine vermiculite; ${ }^{\text {w} R i c e ~ h u s k ; ~}{ }^{\mathrm{v}}$ Variation coefficient. ns - not significant (Tukey $\mathrm{p}<0,05$ ). 
The net carbon assimilation $(A)$, transpiration $(E)$, water use efficiency $(A / E)$, and stomatal conductance $\left(g_{s}\right)$ parameters remained unaffected by substrates used. The $A, E, A / E$, and $g$ salues were on average $4.36 \mu \mathrm{mol} \mathrm{m}{ }^{-2}$

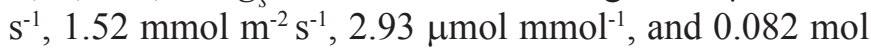
$\mathrm{m}^{-2} \mathrm{~s}^{-1}$, respectively (Table 5). Therefore, the different substrates did not interfere in the physiological aspects of the photosynthetic apparatus of cagaita seedlings. Chlorophyll $a$ fluorescence variables remained unaffected by substrates tested, with mean value of 219 for minimum fluorescence $\left(F_{0}\right)$. The mean maximum quantum yield of PSII $\left(F_{v} / F_{m}\right)$, effective quantum yield of PSII $(\phi P S I I)$, regulated non-photochemical energy dissipation $(\phi N P Q)$, and unregulated non-photochemical energy dissipation of PSII $(\phi N O)$ values were $0.74,0.227,0.733$, and 0.340 , respectively. The effective quantum yield of PSII $(\phi P S I I)$ was lower than $\phi N P Q$ and $\phi N O$. Therefore, the photosynthetic yield, i.e., the amount of energy absorbed by chlorophyll that is directed to the generation of reducing power (ATP and NADPH), was lower than the regulated and unregulated non-photochemical energy dissipation of PSII. This indicates the existence of photoinhibition, most likely caused by some stress factor(s), because high $\phi N P Q$ value indicates dissipation of energy absorbed in the form of heat by the xanthophyll cycle (BARALDI et al., 2008).
Substrates did not affect the electron transport rate $\left(E T R\right.$ ), with mean value of $86.63 \mu \mathrm{mol} \mathrm{m}^{-2} \mathrm{~s}^{-1}$ (Table 6). Lemos-Filho (2000) found ETR of approximately $110 \mu \mathrm{mol} \mathrm{m}^{-2} \mathrm{~s}^{-1}$ in the dry season and approximately 200 $\mu \mathrm{mol} \mathrm{m} \mathrm{m}^{-2} \mathrm{~s}^{-1}$ in the rainy season for fruit tree seedlings of the Brazilian Cerrado, including cagaita. The stomatal conductance values $\left(g_{s}\right)$ found in this study are lower than those observed by Lemos-Filho (2000), who found $g_{s}$ of $0.26 \mathrm{~mol} \mathrm{~m}^{-2} \mathrm{~s}^{-1}$ in plants under field conditions during the rainy season. Neves et al. (2009) found $g_{s}$ of $0.14 \mathrm{~mol} \mathrm{~m}^{-2} \mathrm{~s}^{-1}, A$ of $12 \mu \mathrm{mol} \mathrm{m} \mathrm{s}^{-2} \mathrm{~s}^{-1}$, and $E$ of $1.2 \mathrm{mmol}$ $\mathrm{m}^{-2} \mathrm{~s}^{-1}$ in young $E$. uniflora plants hydroponically grown, i.e., under optimal nutritional and water conditions. Water use efficiency $(A / E)$ in the present study was $2.85 \mu \mathrm{mol}$ of $\mathrm{CO}_{2} \mathrm{mmol}^{-1}$ of $\mathrm{H}_{2} \mathrm{O}$, i.e., for each mol of fixed $\mathrm{CO}_{2}$, $351 \mathrm{~mol}^{\circ} \mathrm{H}_{2} \mathrm{O}$ were transpired, which is an intermediate value between $\mathrm{C} 4$ and $\mathrm{C} 3$ plants (BACON, 2004). The $F_{v} / F_{m}$ values are lower than 0.8 , which is indicative of stress (NEVES et al., 2009). In the current study, the $F_{v} /$ $F_{m}$ values were less than 0.73 , suggesting the presence of at least one stress factor.

Table 5 - Net $\mathrm{CO}_{2}$ assimilation rate $(A)$, transpiration $(E)$, water use efficiency $(A / E)$, and stomatal conductance $\left(g_{s}\right)$ in Eugenia dysenterica DC seedlings as a function of substrates. Rio Verde, 2016.

\begin{tabular}{|c|c|c|c|c|}
\hline Substrate & A & $E$ & $A / E$ & $g_{s}$ \\
\hline & $\mu \mathrm{mol} \mathrm{m} \mathrm{m}^{-2} \mathrm{~s}^{-1}$ & $\mathrm{mmol} \mathrm{m}^{-2} \mathrm{~s}^{-1}$ & $\mu \mathrm{mol} \mathrm{\textrm {mmol } ^ { - 1 }}$ & $\mathrm{mol} \mathrm{m}^{-2} \mathrm{~s}^{-1}$ \\
\hline Trimix $^{\circledR}$ & $3.94^{\mathrm{ns}}$ & $1.74^{\mathrm{ns}}$ & $2.46^{\text {ns }}$ & $0.08^{\mathrm{ns}}$ \\
\hline $\mathrm{FV}^{\mathrm{x}}$ & 4.92 & 1.85 & 2.93 & 0.12 \\
\hline $\mathrm{FV}+\mathrm{RH}^{\mathrm{w}}(3: 1)$ & 2.89 & 0.91 & 3.29 & 0.05 \\
\hline FV+RH(1:1) & 4.91 & 1.83 & 2.73 & 0.12 \\
\hline $\mathrm{FV}+\mathrm{RH}(1: 3)$ & 4.12 & 1.59 & 2.83 & 0.08 \\
\hline $\mathrm{VC}^{\mathrm{v}}$ & 43.65 & 52.07 & 36.90 & 71.98 \\
\hline
\end{tabular}

ns - not significant (Tukey $\mathrm{p}<0,05$ ).

Table 6- Maximum quantum yield of PSII $\left(F_{v} / F_{m}\right)$, effective quantum yield of PSII ( $\left.\phi P S I I\right)$, quantum yield of regulated non-photochemical energy dissipation $(\phi N P Q)$, quantum yield of unregulated non-photochemical energy dissipation of PSII $(\phi N O)$, and electron transport rate (ETR) of Eugenia dysenterica DC seedlings as a function of substrates. Rio Verde, 2016.

\begin{tabular}{lllllc}
\hline Substrate & $F_{v} / F_{m}$ & $\phi P S I I$ & $\phi N P Q$ & $\phi N O$ & $E T R$ \\
\hline Trimix $^{\circledR}$ & & & & & $\mu \mathrm{mol} \mathrm{m}^{-2} \mathrm{~s}^{-1}$ \\
$\mathrm{FV}^{\mathrm{x}}$ & $0.73^{\mathrm{ns}}$ & $0.24^{\mathrm{ns}}$ & $0.44^{\mathrm{ns}}$ & $0.32^{\mathrm{ns}}$ & $97.60^{\mathrm{ns}}$ \\
$\mathrm{FV}^{\mathrm{Rs}} \mathrm{RH}^{\mathrm{w}}(3: 1)$ & 0.68 & 0.19 & 0.48 & 0.33 & 76.14 \\
$\mathrm{FV}+\mathrm{RH}(1: 1)$ & 0.69 & 0.20 & 0.43 & 0.37 & 77.47 \\
$\mathrm{FV}+\mathrm{RH}(1: 3)$ & 0.73 & 0.31 & 0.34 & 0.35 & 118.31 \\
\hline $\mathrm{VC}^{\mathrm{v}}$ & 0.73 & 0.27 & 0.40 & 0.33 & 107.85 \\
\hline
\end{tabular}

ns - not significant (Tukey $\mathrm{p}<0,05$ ). 
For the growth characteristics evaluated, only stem diameter (SD) was affected by substrates. FV showed higher SD compared to FV+RH (1:3), with values of 1.06 and $0.92 \mathrm{~mm}$, respectively; the other substrates did not differ from these. Stem length (SL), number of leaves $(\mathrm{NL})$, and leaf area (LA) showed mean values of $2.51 \mathrm{~cm}$, 2.2 leaves, and $14.7 \mathrm{~cm}^{2}$, respectively. Leaf, stem, root, and total accumulated dry weight were also unaffected by substrates, exhibiting mean values of $0.12,0.018,0.44$, and $0.59 \mathrm{~g}$, respectively (Table 7). The lack of differences in the biometric characteristics of $E$. dysenterica seedlings as a function of substrates may also be due to the lack of differences in gas exchange values. Although low, SL and SD values were similar to those found by Melo and Haridasan (2009) in E. dysenterica at similar age; however, SL and NL values found were lower than those observed by Nietsche et al. (2004). The partition of the accumulated dry weight was a notable characteristic, and the root system was responsible for $70 \%$ to $80 \%$ of the accumulated TDW. According to Silveira et al. (2013), E. dysenterica commonly prioritizes root system development to the detriment of shoots, and the initial growth of shoots is slow, which corroborates the results found in the present study.
Regarding the indexes used to evaluate $E$. dysenterica seedling quality, only DQI was affected by substrates, and pure vermiculite led to higher values compared to substrates containing vermiculite mixed with rice husk at all ratios. Trimix ${ }^{\circledR}$ yielded DQI similar to the other substrates used for $E$. dysenterica seedling production. The other quality indexes, such as stem length / stem diameter ratio (SL/SD), stem length / shoot dry weight ratio (SL/S), and root dry weight / shoot dry weight ratio $(\mathrm{R} / \mathrm{S})$, exhibited mean values of $3.09 \mathrm{~cm}$ $\mathrm{mm}^{-1}, 19.48 \mathrm{~cm} \mathrm{~g}^{-1}$ and $2.76 \mathrm{~g} \mathrm{~g}^{-1}$, respectively (Table 8 ). The SL/SD ratio found was lower than that observed by Souza et al. (2001), who reported values close to $6.0 \mathrm{~cm}$ $\mathrm{mm}^{-1}$, suggesting that the plants of the present study have higher quality because they exhibited lower etiolation; however, further studies are necessary to support this assumption. Another quality index, the $\mathrm{R} / \mathrm{S}$ ratio, indicates that the substrates tested provided higher photoassimilate allocation to the root system, a characteristic usually exhibited by plants under water or nutritional stress. However, this type of photoassimilation is characteristic of this species, which prioritizes initial root system development (SILVEIRA et al., 2013). R/S ratio close to 1.0 was verified by Souza et al. (2001) and close to 1.4 by Paiva Sobrinho et al. (2010), which are lower than values found the present study. Duarte et al. (2006) found values closer to those of the present study, ranging from 1.9 to 3.1, but still lower. Melo and Haridasan (2009) found higher values, above 5.0; these authors also found that, as the nutrient concentration in the soil increased, the R/S ratio decreased.

Table 7 - Stem length $(S L)$; stem diameter $(S D)$; number of leaves $(N L)$; leaf area $(L A)$; and stem $(S D W)$, leaf $(L D W)$, root $(R D W)$, and total dry weights $(T D W)$ of Eugenia dysenterica DC seedlings as a function of substrates. Rio Verde, 2016.

\begin{tabular}{|c|c|c|c|c|c|c|c|c|}
\hline Substrate & $S L$ & $S D$ & $N L$ & $L A$ & $S D W$ & $L D W$ & $R D W$ & $T D W$ \\
\hline & $(\mathrm{cm})$ & $(\mathrm{mm})$ & & $\left(\mathrm{cm}^{2}\right)$ & \multicolumn{4}{|c|}{ 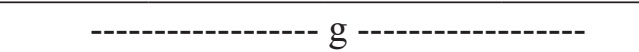 } \\
\hline Trimix $^{\circledR}$ & $2.42^{\mathrm{ns}}$ & $1.00 \mathrm{ab}$ & $2.20^{\text {ns }}$ & $15.63^{\mathrm{ns}}$ & $0.018^{\mathrm{ns}}$ & $0.140^{\mathrm{ns}}$ & $0.449^{\text {ns }}$ & $0.639^{\mathrm{ns}}$ \\
\hline $\mathrm{FV}^{\mathrm{x}}$ & 2.46 & $1.06 \mathrm{a}$ & 2.24 & 15.87 & 0.019 & 0.129 & 0.491 & 0.607 \\
\hline $\mathrm{FV}+\mathrm{RH}^{\mathrm{w}}(3: 1)$ & 2.52 & $0.98 \mathrm{ab}$ & 2.36 & 14.52 & 0.018 & 0.130 & 0.419 & 0.591 \\
\hline $\mathrm{FV}+\mathrm{RH}(1: 1)$ & 2.69 & $0.96 \mathrm{ab}$ & 2.16 & 15.51 & 0.020 & 0.128 & 0.444 & 0.567 \\
\hline $\mathrm{FV}+\mathrm{RH}(1: 3)$ & 2.50 & $0.92 \mathrm{~b}$ & 2.12 & 12.20 & 0.018 & 0.101 & 0.429 & 0.547 \\
\hline $\mathrm{VC}^{\mathrm{v}}$ & 25.79 & 15.20 & 27.24 & 34.41 & 45.19 & 59.27 & 26.58 & 24.18 \\
\hline
\end{tabular}

*Means followed by the same letter in the column do not differ according to Tukey's test ( $<0.05)$; ${ }^{\text {} F i n e ~ v e r m i c u l i t e ; ~}{ }^{\text {w} R i c e ~ h u s k ; ~}{ }^{\mathrm{v}}$ Variation coefficient. ns - not significant (Tukey $\mathrm{p}<0,05$ ). 
$\mathrm{P}, \mathrm{Ca}$, and $\mathrm{S}$ levels in leaves did not differ among the substrates tested, showing mean values of 1.0, 15.9, and $0.6 \mathrm{mg} \mathrm{g}^{-1}$, respectively (Table 9). The leaf Mg levels only differed between Trimix ${ }^{\circledR}$ and FV substrates, 7.9 and $12.0 \mathrm{mg} \mathrm{g}^{-1}$, respectively. FV+RH (1:1) substrate exhibited the lowest leaf $\mathrm{N}$ content $\left(10.8 \mathrm{mg} \mathrm{g}^{-1}\right)$ compared to the other substrates; $\mathrm{FV}$ yielded higher leaf $\mathrm{N}$ content compared to $\mathrm{FV}+\mathrm{RH}$ at $3: 1$ and $1: 3$ ratios, with values of 17.6, 16.0, and $16.0 \mathrm{mg} \mathrm{g}^{-1}$, respectively. Regarding the leaf $\mathrm{K}$ content, higher variation was observed (Table 9). Trimix $^{\circledR}$ exhibited the highest value $\left(11.0 \mathrm{mg} \mathrm{g}^{-1}\right)$, followed by $\mathrm{FV}+\mathrm{RH}(1: 3)$ with value of $7.2 \mathrm{mg} \mathrm{g}^{-1}$; the lowest value was found for FV (2.4 $\left.\mathrm{mg} \mathrm{g}^{-1}\right)$; and the other substrates showed values between FV and FV+RH (1:3), with no significant differences. Melo and Haridasan (2009) found leaf $\mathrm{N}, \mathrm{P}, \mathrm{K}, \mathrm{Ca}$ and $\mathrm{Mg}$ contents of 15.0, 1.3, 6.8, 16.9 and $3.1 \mathrm{mg} \mathrm{g}^{-1}$, respectively, for the highest doses of each nutrient in the soil; the $\mathrm{S}$ leaf content was $0.4 \mathrm{mg} \mathrm{g}^{-1}$ at all doses and measurements were made at 345 days after sowing. The values found by these authors for N, Ca, S, and $\mathrm{P}$ are similar to those found in the present study. The mean leaf $\mathrm{K}$ content was similar, but ranged from 2.4 to 11 in the present study using FV and Trimix ${ }^{\circledR}$ substrates, respectively. The leaf $\mathrm{K}$ content increased according to increasing proportion of rice husk, indicating that rice husk can be a source of $\mathrm{K}$ for plants. The leaf $\mathrm{Mg}$ content was approximately four times higher than that found by Melo and Haridasan (2009).

Table 8 - Stem length / stem diameter ratio $(S L / S D)$, root / shoot dry weight ratio (R/S), and Dickson's quality index (DQI) of Eugenia dysenterica DC seedlings as a function of substrates. Rio Verde, 2016.

\begin{tabular}{lccl}
\hline Substrate & SL/SD & $\mathrm{R} / \mathrm{S}$ & $\mathrm{DQI}$ \\
\hline & $\left(\mathrm{cm} \mathrm{mm} \mathrm{mm}^{-1}\right)$ & $\left(\mathrm{g} \mathrm{g}^{-1}\right)$ & \\
Trimix $^{\circledR}$ & $2.49^{\mathrm{ns}}$ & $3.51^{\mathrm{ns}}$ & $0.22 \mathrm{ab}$ \\
$\mathrm{FV}^{\mathrm{x}}$ & 2.37 & 3.56 & $0.25 \mathrm{a}$ \\
$\mathrm{FV}+\mathrm{RH}^{\mathrm{w}}(3: 1)$ & 2.58 & 3.34 & $0.20 \mathrm{~b}$ \\
$\mathrm{FV}+\mathrm{RH}(1: 1)$ & 2.81 & 3.19 & $0.20 \mathrm{~b}$ \\
$\mathrm{FV}+\mathrm{RH}(1: 3)$ & 2.76 & 3.89 & $0.19 \mathrm{~b}$ \\
\hline $\mathrm{VC}^{\mathrm{v}}$ & 27.77 & 32.20 & 34.78 \\
\hline
\end{tabular}

Means followed by the same letter in the column do not differ according to Tukey's test $(\mathrm{p}<0.05)$; ${ }^{\mathrm{x}}$ Fine vermiculite; ${ }^{\mathrm{w}}$ Rice husk; ${ }^{\mathrm{v}}$ Variation coefficient. ns - not significant (Tukey $\mathrm{p}<0,05$ ).

Table 9- Macronutrients in leaves of Eugenia dysenterica DC seedlings as a function of substrates. Rio Verde, 2016.

\begin{tabular}{|c|c|c|c|c|c|c|}
\hline Substrate & $\mathrm{N}$ & $\mathrm{P}$ & K & $\mathrm{Ca}$ & $\mathrm{Mg}$ & $\mathrm{S}$ \\
\hline & \multicolumn{6}{|c|}{$-\mathrm{mg} \mathrm{g}^{-1}$} \\
\hline $\operatorname{Trimix}^{\circledR}$ & $17.0 \mathrm{ab}$ & $1.08^{\mathrm{ns}}$ & $11.0 \mathrm{a}$ & $18.4^{\mathrm{ns}}$ & $7.9 b$ & $0.44^{\text {ns }}$ \\
\hline $\mathrm{FV}^{\mathrm{x}}$ & $17.6 \mathrm{a}$ & 1.12 & $2.4 \mathrm{~d}$ & 18.9 & $12.0 \mathrm{a}$ & 0.74 \\
\hline $\mathrm{FV}+\mathrm{RH}^{\mathrm{w}}(3: 1)$ & $16.0 \mathrm{~b}$ & 0.96 & $3.8 \mathrm{~cd}$ & 10.4 & $9.4 \mathrm{ab}$ & 0.52 \\
\hline FV+RH(1:1) & $10.8 \mathrm{c}$ & 0.88 & $5.4 \mathrm{bc}$ & 12.2 & $10.3 \mathrm{ab}$ & 0.60 \\
\hline $\mathrm{FV}+\mathrm{RH}(1: 3)$ & $16.0 \mathrm{~b}$ & 0.96 & $7.2 \mathrm{~b}$ & 19.4 & $9.4 \mathrm{ab}$ & 0.62 \\
\hline $\mathrm{VC}^{\mathrm{v}}$ & 16.59 & 17.32 & 56.34 & 44.07 & 24.18 & 37.37 \\
\hline
\end{tabular}

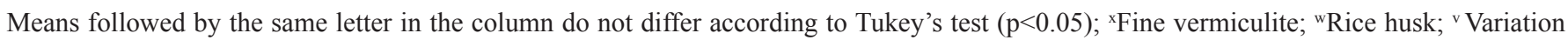
coefficient. ns - not significant (Tukey $\mathrm{p}<0,05$ ).

\section{Conclusions}

The increase in the proportion of rice husk mixed with vermiculite results in reduction in the dry and moist densities of substrates, available water, remaining water, total porosity and moisture content, and increases the aeration space in substrates. The fine vermiculite substrate promotes the highest Dickson's quality index and the greatest stem diameter of plants. Seedlings grown on vermiculite substrate presented higher leaf $\mathrm{N}$ and $\mathrm{K}$ contents, and those grown in Trimix ${ }^{\circledR}$ substrate showed higher leaf $\mathrm{Mg}$ content. Substrates did not change the physiological attributes of Cagaiteira seedlings.

\section{Acknowledgements}

The Higher Education Personnel Improvement Coordination (CAPES), the Goiás Research Foundation (FAPEG) for the financial support and fellowships granted, and Mr. Arlindo Thomáz da Silva and family for providing the plant material. 


\section{References}

ARAÚJO NETO, S.E.; AZEVEDO, J.M.A.; GALVÃO, R.O.; OLIVEIRA, E.B.L.; FERREIRA, R. L. F. Produção de muda orgânica de pimentão com diferentes substratos. Ciência Rural, Santa Maria, v.39, n.5, p.1408-1413, 2009.

BACON, M. Water use efficiency in plant biology. Boca Raton: Blackwell Publishing, 2004. 45p.

BAILÃO, E.; DEVILLA, I.; CONCEIÇÃO, E.; BORGES, L. Bioactive compounds found in Brazilian Cerrado fruits. International Journal of Molecular Sciences, Basel, v.16, n.10, p.23760-23783, 2015.

BARALDI, R.; CANACCINI, F.; CORTES, S.; MAGNANI, F.; RAPPARINI, F.; ZAMBONI,A.; RADDI, $\mathrm{S}$. Role of xanthophyll cycle-mediated photoprotection in arbutus unedo plants exposed to water stress during the Mediterranean summer. Photosynthetica, Prague, v.46, n.3, p.378-386, 2008.

BILGER, W.; SCHREIBER, U.; BOCK, M. Determination of the quantum efficiency of photosystem II and of nonphotochemical quenching of chlorophyll fluorescence in the field. Oecologia, Berlin, v.102, n.4, p.425-432, 1995.

CARDOSO, L.M.; MARTINO, H.S.D.; MOREIRA, A.V.B.; RIBEIRO, S.M.R.; PINHEIRO-SANT'ANA, H.M. Cagaita (Eugenia dysenterica DC.) of the Cerrado of Minas Gerais, Brasil: physical and chemical characterization, carotenoids and vitamins. Food Research International, Barking, v.44, n.7, p.2151-5154, 2011.

COSTA, T.R.; FERNANDES, O.F.L.; SANTOS, S.C.; OLIVEIRA, C.M.A.; LIÃO, L.M.; FERRI, P.H.; PAULA, J.R.; FERREIRA, H.D.; SALES, B.H.N.; SILVA, M.R.R. Antifungal activity of volatile constituents of Eugenia dysenterica leaf oil. Journal of Ethnopharmacology, Lausanne, v.72, n.1-2, p.111-117, 2000.

DANTAS, B.F.; LOPES, A.P.; SILVA, F.F.S.; LÚCIO, A.L.; BATISTA, P.F.; PIRES, M.M.M.L.; ARAGÃO, C.A. Taxas de crescimento de mudas de catingueira submetidas a diferentes substratos e sombreamentos. Revista Árvore, Viçosa, MG, v.33, n.3, p.413-423, 2009.

DE BOODT, M.; VERDONCK, O.; CAPPAERT, I. Method for measuring the water release curve of organic substrates. Acta Horticulturae, Wageningen, v.37, p.2054-2062. 1974.
DELARMELINA, W.M.; CALDEIRA, M.V.W.; FARIA, J.C.T.; GONÇALVES, E.O.; ROCHA, R.L.F. Diferentes substratos para a produção de mudas de Sesbania virgata. Floresta e Ambiente, Seropédica, v.21, n.2, p.224-233, 2014.

DICKSON, A.; LEAF, A.L.; HOSNER, J.F. Quality appraisal of white spruce and white pine seedling stock in nurseries. Forestry Chronicle, Toronto, v.36, n.1, p.10-13, 1960 .

DRZAL, M.S.; CASSEL, D.K.; FONTENO, W.C. Pore fraction analysis: a new tool for substrate testing. Acta Horticulturae, Wageningen, v.1, n.481, p 43-53, 1999.

DUARTE, E.F.; NAVES, R.V.; BORGES, J.D.; GUIMARÃES, N.N.R. Germinação e vigor de sementes de cagaita (Eugenia dysenterica Mart. ex. DC.) em função de seu tamanho e tipo de coleta. Pesquisa Agropecuária Tropical, Goiânia, v.36, n.3, p.173-179, 2006.

FERMINO, M.H.; GONÇALVES, R.S.; BATTISTIN, A.; SILVEIRA, J.R.P.; BUSNELLO, A.C.; TREVISAM, M. Aproveitamento dos resíduos da produção de conserva de palmito como substrato para plantas. Horticultura Brasileira, Vitória da Conquista, v.28, n.3, p.282-286, 2010.

FERRAZ, M.V.; CENTURION, J.F.; BEUTLER, N.A. Caracterização física e química de alguns substratos comerciais. Acta Scientiarum, Maringá, v. 27, n.2, p.209214, 2005.

GOMES, J.M.; COUTO, L.; LEITE, H.G.; XAVIER, A.; GARCIA, S.L.R. Crescimento de mudas de Eucalyptus grandis em diferentes tamanhos de tubetes e fertilização NPK. Revista Árvore, Viçosa, MG, v.27, n.2, p.113-127, 2003.

GUERRINI, I.A.; TRIGUEIRO, R.M. Atributos físicos e químicos de substratos compostos por biossólidos e casca de arroz carbonizada. Revista Brasileira de Ciência do Solo, Lavras, v.28, n.6, p.1069-1076, 2004.

HENDRICKSON, L.; FURBANK, R.T.; CHOW, W.S.A simple alternative approach to assessing the fate of absorbed light energy using chlorophyll fluorescence. Photosynthesis Research, Dordrecht, v.82, n.1, p.73-81, 2004.

KÄMPF, A.N. Produção comercial de plantas Ornamentais. Guaíba: Agropecuária, 2000. 254p.

LEMOS-FILHO, J.P. Fotoinibição em três espécies do cerrado (Annona crassifolia, Eugenia dysenterica e Campomanesia adamantium) na estação seca e na chuvosa. Revista Brasileira de Botânica, São Paulo, v.23, n.1, p.45-50, 2000. 
LIMA, T.B.; SILVA, O.N.; OLIVEIRA, J.T.A.; VASCONCELOS, I.M.; SCALABRIN, F.B.; ROCHA, T.L.; GROSSI-DE-SÁ, M.F.; SILVA, L.P.; GUADAGNIN, R.V.; QUIRINO, B.F.; CASTRO, C.F.S.; LEONARDECZ, E.; FRANCO, O.L. Identification of E. dysenterica laxative peptide: A novel strategy in the treatment of chronic constipation and irritable bowel syndrome. Peptides, New York, v.31, n.8, p.1426-1433, 2010.

MAGUIRE, J.D. Speed of germination - aid in selection and evaluation for seedling and vigour. Crop Science, Madison, v.2, n.1, p.176-177, 1962.

MALAVOLTA, E.; VITTI, G.C.; OLIVEIRA A.S. Avaliação do estado nutricional das plantas princípios e aplicações. 2.ed. Piracicaba: Associação Brasileira para Pesquisa da Potássio e do Fosfato, 1997. 319p.

MARTINS, C.C.; MACHADO, C.G.; CALDAS, I.G.R.; VIEIRA, I.G. Vermiculita como substrato para o teste de germinação de sementes de barbatimão. Ciência Florestal, Santa Maria, v.21, n.3, p.421-427, 2011.

MELO, J.T.; HARIDASAN, M. Respostas de mudas de cagaita (Eugenia dysenterica $\mathrm{DC}$ ) a doses de $\mathrm{N}, \mathrm{P}$, K, Ca e Mg. Planaltina: Embrapa Cerrados, 2009. 27p. (Boletim de Pesquisa, 234).

NEVES, N.R.; OLIVA, M.A.; CENTENO, D.; COSTA, A.C.; RIBAS, R.F.; PEREIRA, E.G. Photosynthesis and oxidative stress in the restinga plant species Eugenia uniflora L. Exposed to simulated acid rain and iron ore dust deposition: potential use in environmental risk assessment. Science of The Total Environment, Amsterdan, v.407, n. 12, p.3740-3745, 2009.

NIETSCHE, S.; GONÇALVES, V.D.; PEREIRA, M.C.T.; SANTOS, F.A.; ABREU, S.C.; MOTA, W.F. Tamanho da semente e substratos na germinação e crescimento inicial de mudas de cagaiteira. Ciência e Agrotecnologia, Lavras, v.28, n.6, p.1321-1325, 2004.

NOGUEIRA, R.J.M.C.; ALBUQUERQUE, M.B.; SILVA JÚNIOR, J.F. Efeito do substrato na emergência, crescimento e comportamento estomático em plantas de mangabeira. Revista Brasileira de Fruticultura, Jaboticabal, v.25, n.1, p.15-18, 2003.
PAIVA SOBRINHO, S.; LUZ, P.B.; SILVEIRA, T.L.S.; RAMOS, D.; NEVES, L.G.; BARELLI, M.A.A. 2010. Substratos na produção de mudas de três espécies arbóreas do cerrado. Revista Brasileira de Ciências Agrárias, Recife, v.5, n.2, p.238-243, 2010.

PENNINGSFELD, F. Kultursubstrate fur den gartenbau, besonders in Deutschland: ein kritischer Überblick. Plant and Soil, The Hague, v.75, p.269-281, 1983.

RÖBER R; SCHALLER K. Pflanzenernährung im Gartenbau. Stuttgart: Ulmer, 1985. 352p.

SILVA, R.B.G.; SIMÕES, D.; SILVA, M.R. Qualidade de mudas clonais de Eucalyptus urophylla x E. grandis em função do substrato. Revista Brasileira de Engenharia Agrícola e Ambiental, Campina Grande, v.16, n.3, p.297$302,2012$.

SILVEIRA, C.E.S.; PALHARES, D.; PEREIRA, L.A.R.; PEREIRA, K.B.D.; SILVA, F.A.B. Strategies of plant establishment of two Cerrado species: Byrsonima basiloba Juss. (Malpighiaceae) and Eugenia dysenterica Mart. ex DC (Myrtaceae). Plant Species Biology, Hoboken, v.28, n.2, p.130-137, 2013.

SOUZA, E.R.B.; CARNEIRO, I.F.; NAVES, R.V.; BORGES, J.D.; LEANDRO, W.M.; CHAVES, L.J. Emergência e crescimento de cagaita (Eugenia dysenterica DC.) em função do tipo e do volume de substratos. Pesquisa Agropecuária Tropical, Goiânia, v.31, n.2, p.89-95, 2001.

SOUZA, E.R.B.; NAVES, R.V.; OLIVEIRA, M.F. Início da produção de frutos de cagaiteira (Eugenia dysenterica DC) implantada em Goiânia, Goiás. Revista Brasileira de Fruticultura, Jaboticabal, v.35, n.3, p.906909, 2013.

SOUZA, P.; SALES, P.; SIMEONI, L.; SILVA, E.; SILVEIRA, D.; MAGALHÃES, P. Inhibitory activity of $\alpha$-amylase and $\alpha$-glucosidase by plant extracts from the Brazilian cerrado. Planta Médica, Muttenz, v.78, n.4, p.393-399, 2012.

VERDONCK, O.; GABRIELS, R. Substrate requirements for plants. Acta Horticulturae, Wageningen, v.221, n.1, p.19-23, 1988. 